\title{
EU BORDER CONTROL FOR COMBATING CROSS BORDER CRIME
}

\section{F. Mateaş}

\author{
Florian Mateaş \\ Law and Economics Faculty, Social Sciences Department \\ Agora University of Oradea, Oradea, Romania \\ *Correspondence: Florian Mateaş, Agora University of Oradea, 8 Piaţa Tineretului St., \\ Oradea, Romania \\ E-mail: departament@univagora.ro
}

\begin{abstract}
One area of particular interest, both the European Union and Romania, is the border issue, which requires the setting up of a common institutional framework that embodies all specific courses of action across the EU.

The area of border control and Schengen cooperation, which is very important and at the same time very sensitive, imposed at Community level, a continuous development of legal regulations in order to ensure effective security of the EU's external borders.

Romania's geo-strategic position makes the Black Sea an indispensable part of EuroAtlantic security and prosperity. Many of transnational threats facing Europe come from this region. A big part of the area is dominated by economic stagnation, unsafe and insecure borders, organized crime activities and frozen ethnic conflicts.
\end{abstract}

Keywords: border control, organized crime, risk analysis, target.

\section{Introduction}

Romania's accession to the European Union has resulted in, among other things, establishing new borders of the Community. Thus Romania becomes the eastern limit of the European Union, an important factor, with high share in promoting the interests, values and shared vision of the European space to these areas, the vector of interests of Western democracies, and will support in the future different forms of EU cooperation to other areas of interest. In the process of accession Romania, has assumed a number of responsibilities regarding the security of these new borders, taking care to follow the rules and requirements to ensure a secure environment within the European Union.

In this context, to support the primary objective of the Union's Justice and Home Affairs, to " maintain and develop the Union as an area of freedom, security and justice in which the free movement of persons is ensured in accordance with appropriate measures on border controls, asylum, immigration and the prevention and combating of crime", Romania consistently works for the progressive implementation of the measures necessary to achieve an appropriate level of security of its borders.

These measures are included in the Schengen acquis which Romania was obliged by the Treaty of Accession to the European Union to accept fully it. After 1 January 2007, Romania has entered a new phase, which involves preparing and adopting the necessary measures to eliminate internal border controls subsequent to accession to the Schengen area which is not coming even in 2014 ... certainly not because of the border police.

\section{The development of the international security area}

Romania is preparing systematically for Schengen accession, while conducting activities aimed at integration into the European Union. European integration is based on the concept of freedom based on human rights, democratic institutions and law enforcement. 
These common values have proved to be necessary to ensure peace and prosperity in the European Union, constituting criteria for EU enlargement.

Developments in the international security environment at the beginning of the century and millennium, have radically changed the perception of threats to continental and global security, which resulted in the review of a broad list of concerns, determining policy makers and analysts advised to assert that "the world changed", that a thorough cooperation, to mobilize resources combating unconventional threats.

The analysis of the development of contemporary societies reveals that although the intervention measures and the specialized agencies of social control have intensified against acts of organized crime in many countries there is a resurgence and a duplication representing a social problem whose way of expression and resolution is of interest both for control factors in the field, such as the police, judiciary and administration, and public opinion.

Threats which a decade ago was considered quasi-unanimous, speculations or analytical assumptions were unlikely to materialize now become reality.

In the current international security cannot be defined in a geographical sense, new challenges and new reality of national security involving the construction of a new vision, which involves strengthening cooperation with traditional partners who share the same values and goals. Without an integrated risk management system (described in Chapter 3) and vulnerabilities cannot achieve the national security management system and community. By solving cases and observing the changes, police make proposals to change the legal norms.

\section{The European framework regarding border control}

\subsection{Legal Community instruments for border control}

Area of border control and Schengen cooperation, which is very important and at the same time very sensitive, imposed at Community level, a continuous development of legal regulations in order to ensure effective security of the EU's external borders.

With the accession to the European Union, the border with Ukraine, Moldova and Serbia $(+\mathrm{MN})$ became the external border of the European Union. To secure this border, at national level, there have been implemented most of the objectives set out in policy documents so that, currently, state border control and surveillance is carried out in accordance with the integrated model of border security.

Romanian border authorities as of January 1, 2007 apply to border control and surveillance principles applied by the European Community, as laid down in EU legal instruments.

\subsection{Common policy in the field of border control}

Romania' engagement in Schengen integration led to a series of changes aimed essentially at creating legislative and structural compatibilities harmonizing Romanian institutions with the EU Member States ones and establish measures to ensure rapid implementation of new decisions adopted within the Union.

One area of particular interest, both the Union and Romania, is the border issue, which requires the creation of a common institutional framework that embodies specific courses of action across the EU.

\subsection{External border control}

Member States shall designate national service or services in respect of the staff responsible for the control of border crossings in accordance with their national laws. They will have to ensure staff and resources so as to ensure efficient, high and uniform checks at external borders.

Schengen Catalogue states: External borders control, extradition and readmission: Best practices and recommendations stated that effective border surveillance and control requires adapting the number of staff in risk assessment by analysis".

Schengen Catalogue recommended that staff intended to control border crossings to undergo a course on their future tasks, which should include: knowledge of the provisions of the EU / EC relevant basic rules and procedures, document control ( validity, forgery ), entry 
rules, stay and exit from the country, coordination and cooperation with other agencies, special cooperation between states in the Schengen internal borders, police cooperation, the Schengen Information System, judicial cooperation.

However, it is recommended to continue training in the future, meaning that member institutions should provide programs and facilities at central and local level to assist staff by providing education and training on relevant issues in their work.

In Romania border crossing points are under the subordination of the Ministry of Internal Affairs which coordinates the border control activity and ensures public order through Romanian Border Police ${ }^{1}$.

\subsection{Abolition of controls at internal borders}

In accordance with the definitions adopted by the Schengen Borders Code "internal borders" shall mean the common land borders, including river and lake borders of the Member States, Member States airports for domestic flights and sea ports, river and lakes of the Member States for the links of regular ferry.

Citizens, whether belonging to a third country or enjoying the Community right of free movement, may cross borders in any place without being subject to a prior check. Principle enshrined in the Schengen Agreement of 1985, under which will be removed internal border controls is only applicable to common borders of Schengen Member States and does not require the abolition of borders, as it is often interpreted. The fact that it will abolish checks at internal borders shall not affect in any way the controls within the territory.

\subsection{Characteristics of border control}

The legal basis for the control of these categories is given by: Directive no. 38/2004 (Articles 4, 5 and 27) on the right to free movement and residence in Member States for Union citizens and their family members, Schengen Borders Code (Article 7) and the Agreement between the European Community and its Member States, of the one part, and the Swiss Confederation on the other part, on the free movement of persons.

Before discussing specific border control rules for these categories, we must specify which persons are enjoying the Community right of free movement, but without making reference to the evolution of the concept and its consecration in international legal instruments, European and national.

\subsection{The efficiency of border surveillance activity}

At the national level, to achieve effective supervision of the border we are seeking to adopt, improve and implement best practices of EU countries. To this end the new design was implemented surveillance and border control, which provides the general framework for a unitary approach, consistent with European standards of security concepts and a high level of border control.

The main purposes of border surveillance, identified by the Schengen Borders Code are:

- prevent unauthorized border crossings;

- countering cross-border crime;

- take measures against persons who have crossed the border illegally.

\subsection{Joint border control}

As required by international law, the borders are the " line which determines the limit of the territorial jurisdiction of the state" and present de facto the limits sovereignty, being a sensitive topic in all countries. Meanwhile, the process of European integration and regional cooperation issues grouped border area, often exclusive relationships between two countries, in a separate chapter. Integration into the Schengen area is directly dependent on the success

\footnotetext{
${ }^{1}$ Decision no. 445 of 9 May 2002 for the approval of the methodological norms of implementing the Emergency Ordinance no. 105/2001 regarding the state border.

${ }^{2}$ Art. 2, alin. 1
} 
of each state record in the process of securing their borders, including by improving border control and management by policy standards, principles and community requirements.

Usually, by establishing joint control EU countries are pursuing a number of key objectives such as:

- changing the complicated and lengthy formalities at the border crossing operations making them faster and simpler for individuals and for the transit of goods;

- a border control more efficient and transparent;

- reducing the operating costs of border checkpoints;

- reducing risks of various phenomena difficult to counter, such as corruption and illegal trafficking of goods and people.

\section{Main risks and threats at national security}

Sources of instability, dangers and threats are directly proportional to the evolution of society, with positive effects, but also many contradictory effects. Interestingly, cross-border crime is not a product of a civilization or another, as sometimes is understood, but the degradation of the human condition, the evil that grows increasingly more inside world.

Romania's geo-strategic position makes the Black Sea an indispensable part of EuroAtlantic security and prosperity. Many of transnational threats facing Europe come from this region. A too much of the Basin is dominated by economic stagnation, unsafe and insecure borders, organized crime activities and frozen ethnic conflicts.

Knowledge advances in threatening rhythms and is spreading rapidly and expanded spaces. Traditional pre- industrial societies, national and regional economies, social attitudes and behaviors are interrelated and remodels civilizations face, everything seems to be heading inevitably towards global state. At the beginning of the third millennium it is clear that a new world is born, even if, in some way at least three worlds continue to exist.

\subsection{Operational risk analysis ${ }^{3}$ - Case study}

Stadard, risk analysis" is based on geographical and demographical and leads to a description of the areas of high, normal and low risk. This is used to support the different needs in surveillance. Another standard procedure is to gather strategical data on illegal crossings.

\subsubsection{Border Crossing Points}

In the following we will focus on border crossing points. Here Schengen Borders Code requires a $100 \%$ control of persons crossing the border. Where this requirement is met, it means that every person will meet with a border guard. So everyone will have to have personal travel documents for legal entry or exit. People who do not have travel documents available will be sent back.

But when they occur due to other types of illegal activities, they cannot be discovered during border control measures. Let's take an example of illegal crossing of persons inside the trucks. It is well known that this type of activity takes place several times a day along the EU border. Often it is the poor victim of trafficking networks, one that is hidden in the truck, the person who otherwise will not make any change in crossing the border. To control the contents of a container truck requires a task that requires a lot of time, X-ray machines, $\mathrm{CO} 2$ samples, heartbeat detectors, etc.

\subsubsection{Periodical operations}

Suppose that during a week a joint operation is organized, where the idea of action is to detect activities led by people inside the truck by increasing control over the day. The trucks are randomly selected, because the idea is to collect statistical information available. In a BCP the lower traffic is of 200 trucks per day. Because downloading is hard work, the staff is able to search the 10 trucks, which means $5 \%$ of the total traffic each day. The following figure shows the situation of 200 trucks of which $10(5 \%)$ are controlled.

\footnotetext{
${ }^{3}$ Adapted from Frontex: Operational Risk Analysis 2010-2013.
} 


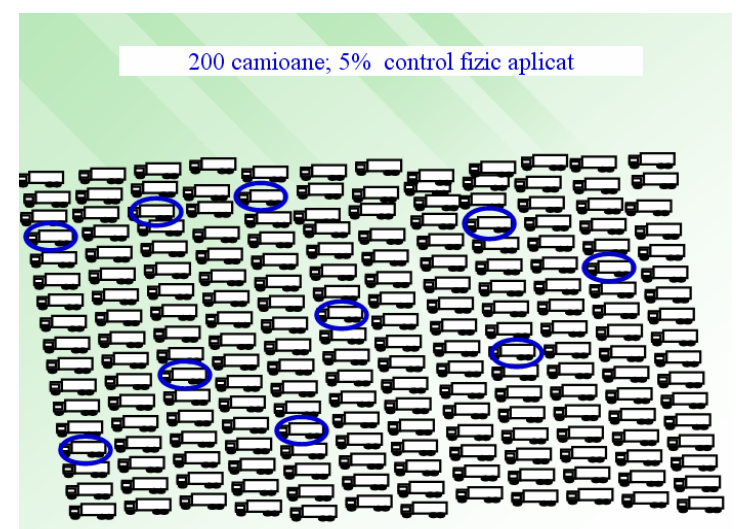

Figure 1. Randomly selected trucks for check

The border guard, reading this, should review their professional history and tell what conclusions can be obtained after such an operation!

Author's experience is as follows: The chief who is responsible will say something like "The result is zero. The test indicates that there are no problems, which is not surprising. Here in the $\mathrm{BCP}$, there are no problems guiding the trucks.

There is another possibility, and it appears at the end of such an operation. In this case, one of the checks provides a positive result that illegal people are discovered in one of the trucks.

Again, the chief will likely conclude: "We normally do not experience any problem on the issue of people inside the truck. However, we have organized an action. I immediately arrested a driver who unfortunately decided to try this type of criminal activity.

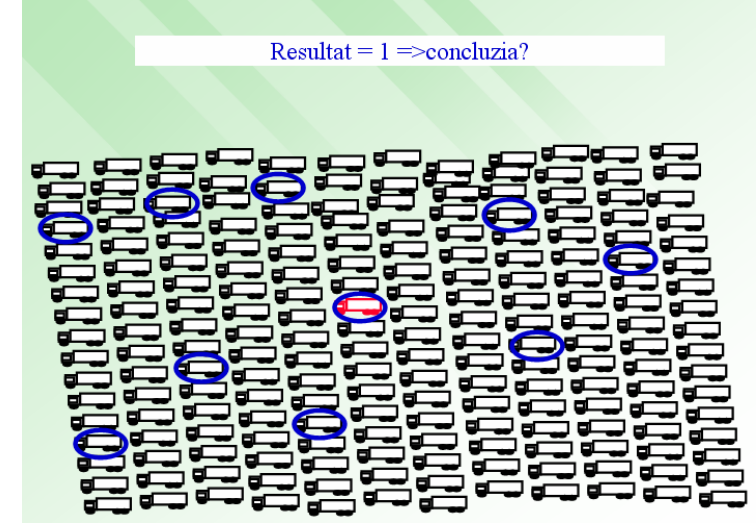

Figure 2. Randomly selected trucks for check with positive result

Commanders (chiefs) work in a culture where facts are more important than speculation. Besides, they deal with media. In this world there is room for "baseless speculation". At this point, we do not deal with the agenda of local managers and local media. Concept, which is now the base, is the common European border control, which has serious implications for the conditions of life and internal security in the EU Member States. So not to be caustic, but critical now! Figure describes how the situation looks in a very important scenario: 


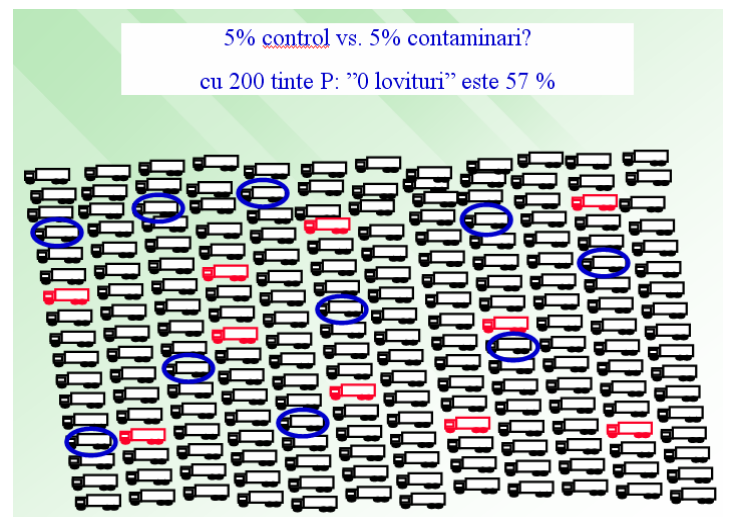

Figure 3. Truck randomly selected for check with real scenario

Statistical science says the following facts absolutely true: if we control $5 \%$ of the trucks and choose targets randomly from a set of 200 trucks, and only 5\% of trucks carrying illegal migrants (red trucks), we can find often 0 hits. The probability that the result is "zero" is $57 \%$.

Zero result does not prove, however, the absence of serious problems. 5\% contamination is an extreme example. The actual level of contamination is lower than the normal considered which in the case study is alarming (such as the situation at the border between Austria and Hungary in 2010, when in a month passed 3,000 Asians).

We should be even more cautious in the case of a seizing. The probability of hitting once is close to $50 \%$ in this awful scenario with $5 \%$ contamination. Together, the probability of hitting the "zero" or "one", is greater than $90 \%$. Other findings from this action are often impossible, even if the threat is very high.

If we make the same extrapolation for the green border, this result "one" suggests the following: we check $5 \%$ and detect a case. That leaves $95 \%$, which means 19 other cases of contamination. The first estimate of the total of offenses is 20 cases. If here we played the God and created a contamination level of 5\%, which means 10 trucks contaminate, we know that the real number of facilitating was only 10, not 20 as they appear in extrapolation.

Academic Question: We have two responses suggested the conventional one "no problem" and the assumed " 20 potential cases of trafficking of migrants"?

Mathematically both lose 10 cases. The first suggests "no further action" and the second can be seen as a "call for serious measures to improve law enforcement". "Knowing" that the actual number of trucks involved was 10, which reply is more important and more realistic estimated in this case?

3.1.3 Constant randomly check

Previous chapter analyzes periodic actions where checks handle a small number of trucks. In statistical terms this is a simple sample taken from a lot smaller. And as we have seen, there is a high risk of not having hits, even for a relatively high crime rate. Zero findings are related to a small lot. In large lots we shall not encounter such difficulties. How close to reality are our findings will always depend on the size of the lot and the number of checked subjects. It would be interesting to define some basic rules for practical application, but they must be made in another setting.

Here, we see another end of this topic: an unlimited lot. When the number of trucks checked is very high, our findings will become a predictable manner. If traffic is contaminated at $5 \%$ level (5\% of trucks carrying migrants), $5 \%$ of randomly selected checks will have a positive outcome. 


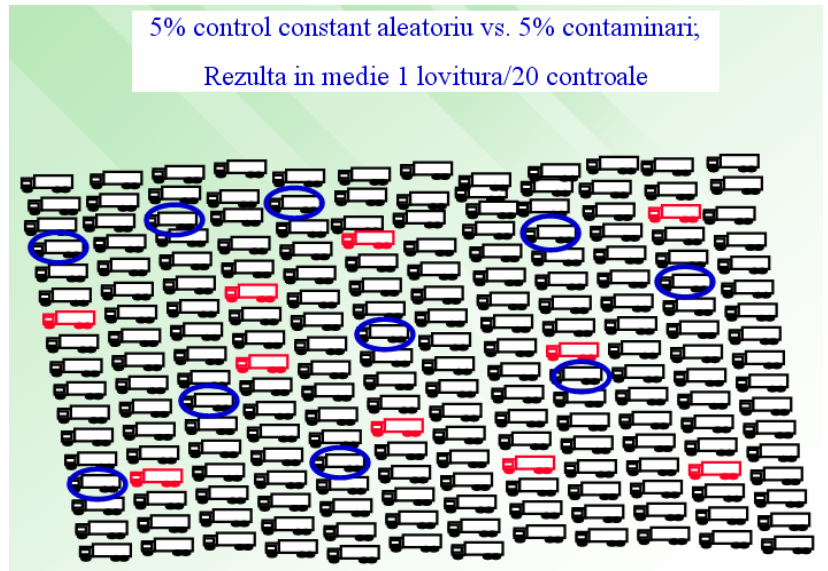

Figure 4. Randomly selected trucks for predictible result

Also in this case, it is important to see all the statistical figures: the control of $5 \%$ of the trucks we find only 5\% of smuggling activities. Annual result of BCP should then be multiplied by 20 to achieve a valid estimate of the total number of illegal activities. This, extrapolation "is the same as that applied in the first instance about green border surveillance.

3.1.4 Targets

As the above examples show, random control is not very effective and comprehensive. Even large work load leads to poor results, and the vast majority of illegal activities remain undetected.

Profiling was described earlier as a function, where information based on information value is used to select targets for control. This should lead to more accurate and thus more cost-effective and better preventive effect.

Let us agree to our example of profiling, joint operations where trucks are sought during exercise. Information workers made risk profiles to be pursued in this exercise. When referring to trucks, indicators can be as follows: country of origin, owner, route, type of goods, etc.

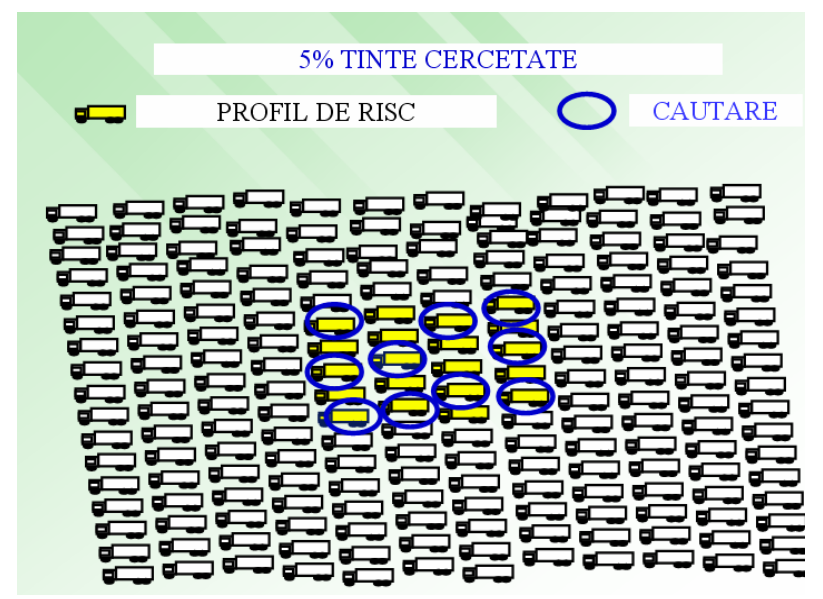

Figure 5.

Again, technical and human resources in the BCP allow only 10 checks during the operation. The next figures show checks based on profilation.

Risk profile does not cover all the crimes. $70 \%$ of the border crossings take place in the trucks that correspond to the risk profile.

The estimated number of hits is 3.5 probably because we hit three or more trucks. Very different from the previous example, where I had to hit just 0 or 1 truck? and again, it is important to see what's behind the statistics. This time you will not have to multiply detections in the way we did in the previous one. The crowd is now the corresponding risk profile. We searched $50 \%$ of them and found three illegal cargos. Conclusion: the 20 trucks that match the risk profile is an average of $2 \times 3=6$ cases in total. 
One can now say that I have done is not enough to count criminal activity: even if we stopped three trucks, seven have passed so the crime is profitable. This conclusion is valid only if we talk about organizing an operation and if we leave things the same after that. But if you maintain this level of control (50\% searches in the group corresponding risk profile), the arrest rate is huge and very soon will reduce illegal crossings. Why?

First, the result of arrest is very damaging for the person involved. In this case, these losses count more than any potential payments for illegal transportation of people.

Another aspect is that maintaining a constant risk of being searched, will make systematic illegal activities of the same individuals become impossible: the risk of being arrested accumulates over time. The following graphic shows the progress over a year. This truck illegally transports people once a month. At the BCP, every time he encounters a risk of arrest of $30 \%$.

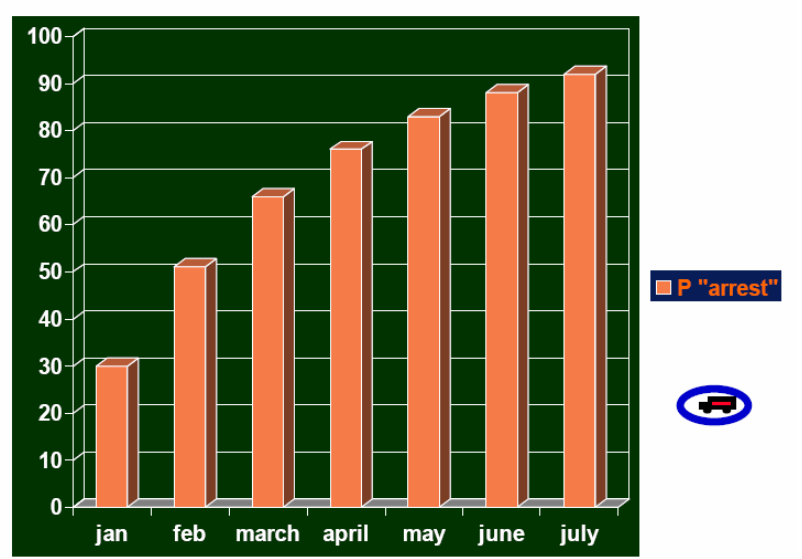

Figure 1. Constant risk for offenders to be searched

The probability of being arrested is almost 50\% in February and June and is almost certain that this truck would be seized. Even a low risk of arrest will block these facilitators to operate continuously. In this example the level of border control is $30 \%$. Much lower than is usually effective.

Let us have one more look at the figures regarding profilation.

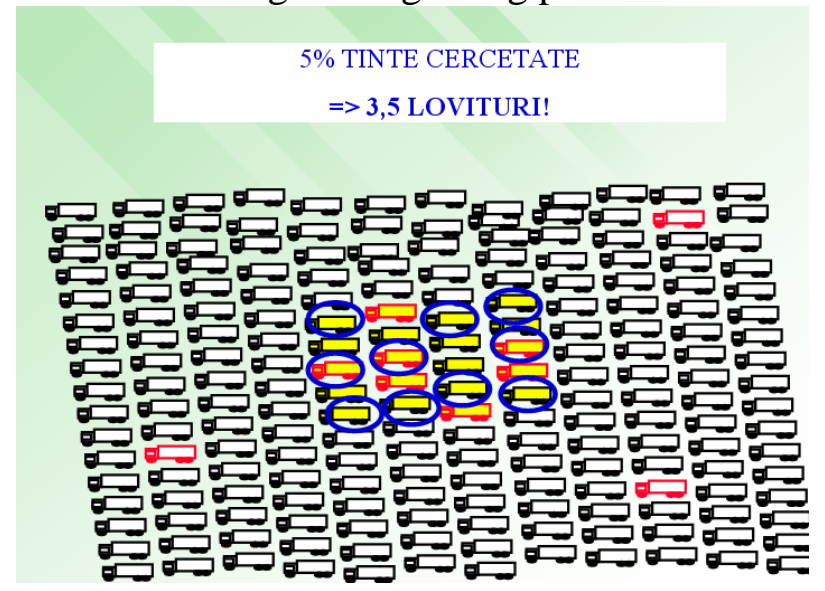

Figure 7. Risk profile of the targets

There are 3 trucks in the black area. As all the profiled trucks will be checked, the other trucks will not be checked. It is very important to know what trucks will be checked because this would mean a possibility for a BG to be corrupt. How do we remedy this? By distributing the decision making power. This means that at every orhanizational level managers may order checks where they consider necessary but the field workers may act upon their own decision. 


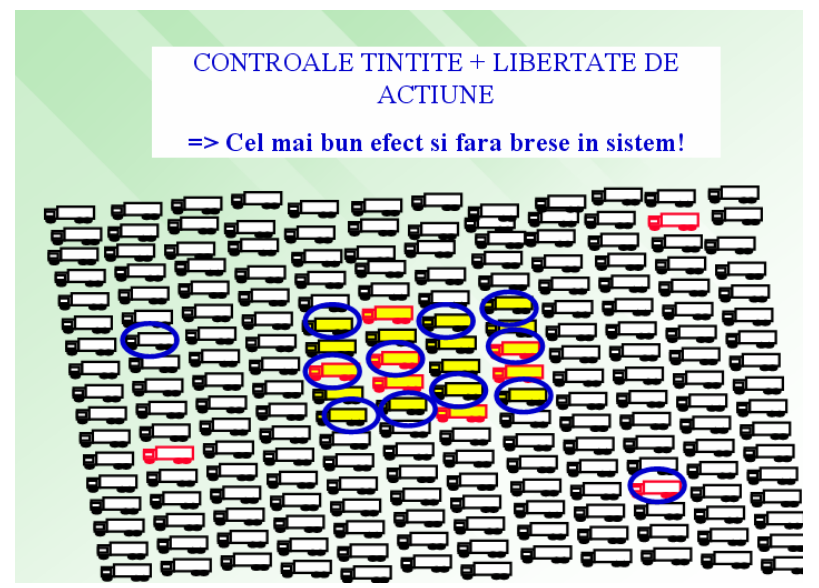

Figure 8. Hit check and intelligence

A good analyst should be able to show how each scenarion can be foreseen. This could be done by paying attention on the initial factors or risk indicators of operational level.

\section{Bibliography}

Burduş E., Căprărescu Gh., Androniceanu A., Miles Michael, (2003), „Managementul schimbării organizaționale", 2nd edition, "Economică" Publishing House, 2003;

Bayley, D.H., Prevenirea şi controlul criminalității în Statele Unite şi Japonia, New York, Dobbs Ferry, 1990. 2004.

Buckingham, M., Coffman, C., Manager contra curentului, Allfa Publishing House,

Dascălu Ioan, Elemente de drept polițienesc, FADROM Publishing House, Bucharest, 2002;

Hobbing, P., Integrated Border Management at the EU Level, CEPS, Brussels 2005;

Hobbing, P., Tracing Terrorists: The EU-Canada Agreement in PNR Matters, CEPS Special Report/September 2008;

Melnic V., Sisteme de supraveghere avansate pentru paza obiectivelor importante, "Alexandru Ioan Cuza" Police Academy, Bucharest, 2009;

Moldoveanu G., Analiza organizațională, "Economică” Publishing House, Bucharest, 2000.

Nicolescu O., Management comparat, second edition, "Economică" Publishing House, Bucharest, 2001;

Moujardet D., O misiune pe un teritoriu: dificultățile polițiştilor de a desfăşura politici de prevenire a delincvenței, Bulletin, Revue du CLCJ, 1991. 2001;

Petrişor Ioan, Management strategic al organizațiilor, "Marineasa" Publishing House,

\section{Online resources}

www.atlanticcomunity.org

www.bologna-berlin2003.de/en/bașic/haupt.htm

www.cepol.europa.eu.

www.eurojust.europa.eu.

www.europol.europa.eu.

www.frontex.europa.eu.

www.guv.ro

www.mai.gov.ro

WwW.migrationpolicy.org

www.ombudsman.europa.eu

www.osce.org.

www.politiadefrontiera.ro

www.schengen.mai.gov.ro 